\title{
Chromosome variations in regenerants of Arabidopsis thaliana derived from 2- and 6-week-old callus detected using flow cytometry and FISH analyses
}

\author{
Maja Orzechowska • Katarzyna Stępień • \\ Teresa Kamińska • Dorota Siwińska
}

Received: 21 May 2012/ Accepted: 5 September 2012/Published online: 15 September 2012

(C) The Author(s) 2012. This article is published with open access at Springerlink.com

\begin{abstract}
Shoot organogenesis was induced from 2- and 6-week-old callus derived from the leaves of Arabidopsis thaliana ecotype Columbia $(2 n=10)$. Regenerated plants were evaluated for chromosomal variations by means of flow cytometry and fluorescent in situ hybridization (FISH). Flow cytometric measurements revealed the occurrence of diploid, tetraploid, and octoploid plants among the regenerants of 2-week-old calli, whereas only diploid and tetraploid plants were regenerated from the 6-week-old calli. Chromosome counting showed that plants developed from the 2-week-old calli exhibited mixoploidy and a high frequency of aneuploid cells. These plants were infertile and displayed altered morphology. FISH with 5S and 25S rDNA probes allowed to detect some structural chromosomal rearrangements in regenerated plants. Along with cells which exhibited correct localisation of rDNA loci, also cells bearing chromosomal translocations, deletions or duplications were found. The type of structural aberrations varied between diploid and tetraploid regenerants.
\end{abstract}

Keywords Organogenesis - Chromosomal aberrations · Flow cytometry · Fluorescent in situ hybridization

Abbreviations
$\begin{array}{ll}2,4-D & 2,4-\text {-Dichlorophenoxyacetic acid } \\ \text { 2iP } & 6-(\gamma, \gamma \text {-Dimethylallylamino) purine } \\ \text { B5 } & \text { Gamborg medium } \\ \text { DAPI } & \text { 4'-6-Diamino-2-phenyloindole } \\ \text { FISH } & \text { Fluorescent in situ hybridization } \\ \text { IAA } & \text { Indole acetic acid }\end{array}$

M. Orzechowska $(\bowtie) \cdot$ K. Stępień · T. Kamińska · D. Siwińska Department of Plant Anatomy and Cytology, University of Silesia, Jagiellonska 28, 40-032 Katowice, Poland e-mail: maja.orzechowska@us.edu.pl $\begin{array}{ll}\text { MS } & \text { Murashige and Skoog } \\ \text { NAA } & \alpha \text {-Naphtalene acetic acid } \\ \text { R1 } & \text { Plants obtained through organogenesis } \\ \text { R2 } & \text { Plants obtained from R1 seeds } \\ \text { rDNA } & \text { Ribosomal DNA } \\ \text { rRNA } & \text { Ribosomal RNA }\end{array}$

\section{Introduction}

Plant tissue culture is one of most important tools necessary for successful conducting plant research and broadly used in commercial biotechnology. It is well known that plants regenerated in vitro undergo genetic and epigenetic changes. A variation originating in cell and tissue culture is referred to as somaclonal variation (Larkin and Scowcroft 1981). Although the occurrence of such variation in organisms derived from in vitro culture may provide new variants that possess economically desirable attributes, it is still unpredictable and uncontrolled, which restricts the utility of tissue cultures (Phillips et al. 1994). The phenomenon of variation in the in vitro culture is one of the most frequently studied phenomena, but the causes of the somaclonal variation remain unclear and therefore cannot be manipulated.

Variation in the number of chromosomes (aneuploidy and polyploidy) and/or their structure is one of the crucial problems in plant cell culture and was reviewed as one of the most significant reasons for the somaclonal variation (Karp 1995; Peschke and Phillips 1992). Karyological changes in cells and tissues cultured in vitro occur both in mitotically dividing cells and in interphase nuclei. The most important alterations include chromosomal aberrations, changes in the content of nuclear DNA, somatic crossing-over and cell cycle disorders. The reason for 
structural chromosomal rearrangements can be late replicating heterochromatin and nucleotide pool imbalance (Lee and Phillips 1988). Karyotypic instability observed during in vitro culture includes chromosome breakage, deletions, translocations and inversions (Jain 2001).

There are numbers of factors which determine the frequency of variation during in vitro culture. They can either be pre-existing in the plant and/or connected to the tissue culture itself. The first group of factors includes the genotype and the nature of the tissue used as a starting material. In most plants the somatic cell differentiation is associated with genome changes that lead to endopolyploidy. The outcome is defined as polysomaty and involves the repeated cycles of replication which are not followed by cell division (D'Amato 1989). Tissue and organ-specific endoreduplication is observed in the model plant Arabidopsis thaliana, where cells with various DNA contents ranging from $2 \mathrm{C}$ to $32 \mathrm{C}$ are present in differentiated organs (Galbraith et al. 1991). Using non-meristematic tissues of A. thaliana as explants resulted in an increased frequency of callus cells with higher ploidy level during the first weeks of in vitro culture (Fras and Maluszynska 2004). Thus the use of non-meristematic mixoploid organs as explants in an in vitro culture can influence from the start the ploidy level of callus cells and the plants regenerated vie callus. The second group of factors which influence the level of somaclonal variation includes culture-dependent conditions. These cover among others the medium composition, the type and concentration of growth regulators, the number and duration of subculture cycles and the method of regeneration (Bairu et al. 2011). A phase of disorganized growth, which occurs during indirect regeneration is one of the fundamental phenomena responsible for the somaclonal variation (Karp 1995).

Detection of structural chromosomal aberrations as well as the changes in chromosome number, including both polyploidy and aneuploidy allow for direct assessment of capital genomic changes and the analyses of variation level in regenerated plants. Flow cytometry allows for rapid and accurate estimation of the nuclear DNA content in thousands of cells and has been widely used for rapid screening of the ploidy levels of regenerated plants like Centaurea ultreiae (Mallón et al. 2010), Vitis vinifera (Prado et al. 2010) or Spathiphyllum (Zhao et al. 2012). Similarly, the analyses of the chromosome numbers and their structural aberrations by means of cytogenetic methods have been successfully employed for detecting the somaclonal variation in plants regenerated in vitro (Do et al. 1999; MolnarLang et al. 2000). Fluorescent in situ hybridization (FISH) proved to be particularly useful for these kind of analyses especially in plants characterized by a low number of small chromosomes, such as A. thaliana. It is well established in A. thaliana for which numerous probes, such as repetitive sequences and chromosome-specific BAC clones, are available (Fransz et al. 1998, Lysak et al. 2001). The rRNA genes are useful chromosomal markers as they are present in each type of cells: they are organized as tandem repeats and their sequence is highly conserved. Two-colour FISH with $25 \mathrm{~S}$ rDNA and 5S rDNA probes enables the identification of most of the chromosomes in the A. thaliana karyotype (Fransz et al. 1998) and can be used to detect large-scale chromosomal rearrangements in plants regenerated from in vitro culture.

In the present study we analyzed ploidy levels, chromosome numbers and structure in plants regenerated from calli after two different periods of preculture. Fast screening of ploidy levels of all obtained plants was performed by means of flow cytometry. From these plants a group of regenerants was chosen for detailed cytogenetic analyses in order to detect if some of the chromosomes or chromosomal segments are preferentially targets of the variation.

\section{Materials and methods}

\section{Plant material and in vitro culture}

Diploid plants of A. thaliana ecotype Columbia $(2 n=2 x=10)$ were used as sources of explants. Axenic plants were obtained from seeds sterilized for $5 \mathrm{~min}$ in a mixture of $3 \% \mathrm{H}_{2} \mathrm{O}_{2}(\mathrm{v} / \mathrm{v}): 70 \%$ (v/v) $\mathrm{EtOH}(1: 1)$, and rinsed five times with sterile distilled water. Seeds were placed in culture vessels containing hormone-free MS medium (Murashige and Skoog 1962) enriched with mineral salts, vitamins, sucrose $(3 \%$, w/v) and agar $(0.8 \%$, w/v). The plants were grown at $21{ }^{\circ} \mathrm{C}, 16$-h photoperiod and $70 \mu \mathrm{mol} \mathrm{m}{ }^{-2} \mathrm{~s}^{-1}$ irradiance. The same growth-room conditions were used for tissue culture. Leaf explants were obtained by cutting young rosette leaves excised from 3-week-old plants into $1 \mathrm{~cm}^{2}$ squares, each with a part of a mid vein. Explants were cultured on a B5 callus-inducing medium (Gamborg et al. 1968) containing $0.5 \mathrm{mg} / \mathrm{L}$ of $2,4-\mathrm{D}$ and $0.05 \mathrm{mg} / \mathrm{L}$ of kinetin (Valvakens et. al 1988). Two and 6-week old calli were transferred on to a shoot-inducing B5 medium supplemented with $0.15 \mathrm{mg} / \mathrm{L}$ of IAA and $5 \mathrm{mg} / \mathrm{L}$ of $2 \mathrm{iP}$ (Valvakens et al. 1988). The regenerated rosettes and shoots were transferred to a root-inducing B5 medium supplemented with $0.125 \mathrm{mg} / \mathrm{L}$ of NAA. These procedures produced regenerated plants (R1), and the next generation phase (R2) was obtained from seeds that were collected from the $\mathrm{R} 1$ regenerants. The $\mathrm{pH}$ of all media was adjusted to 5.8 and autoclaved at $121^{\circ} \mathrm{C}$ for 20 min (Jiang et al. 2011).

Control plants were grown on a hormone-free MS medium in the same conditions as the plants used as the source of explants. 
Flow cytometry

The ploidy levels of the control and regenerated plants were analyzed by flow cytometry. Rosette leaves were chopped and a suspension of nuclei was isolated with an extraction buffer (Dolezel et al. 1998). The samples were filtered through a $30 \mu \mathrm{m}$ nylon mesh (Partec Cell Trics) and stained with DAPI (4'-6-diamino-2-phenyloindole). The measurements were performed with the use of a DAKO Galaxy flow cytometer equipped with an HBO-100 mercury lamp and an argon ion laser.

\section{Mitotic chromosome preparations}

The chromosome number was analyzed in seedling root apical meristems and flower buds of the control plants as well as in the flower buds of the regenerants. Only a few flower buds were fixed from the regenerants to allow for further growth and seed development (R2 generation). The flower buds and seedlings were pre-treated with $2 \mathrm{mM}$ 8-hydroxyquinoline for $2 \mathrm{~h}$ at room temperature and $2 \mathrm{~h}$ at $4{ }^{\circ} \mathrm{C}$ and then fixed overnight in fresh Carnoy's solution (methanol + glacial acetic acid, 3:1, v/v). The fixed material was stored at $-20{ }^{\circ} \mathrm{C}$. The chromosome preparation procedure followed Hasterok et al. (2006), with small modifications. The material was washed in a $0.01 \mathrm{M}$ citrate buffer $\mathrm{pH} 4.8$ and digested with $2 \%$ cellulase "Onozuka" and $20 \%$ pectinase (from Aspergillus niger) at $37^{\circ} \mathrm{C}$ for $45 \mathrm{~min}$ for flower buds and $30 \mathrm{~min}$ for roots. After rinsing and incubation in citrate buffer for $20 \mathrm{~min}$ the material was placed in $45 \%$ acetic acid. Root tips or young flower buds were then placed on a glass slide, dissected and squashed under coverslips. After checking the quality of the chromosome preparations with the use of a phase contrast microscope, the slides were frozen, the coverslips removed, the material refixed in chilled ethanol: acetic acid (3:1), rinsed in absolute ethanol and air dried.

\section{Chromosome number analysis}

The mitotic chromosome preparations were stained with DAPI (4'-6-diamidino-2-phenylindole; $0.5 \mu \mathrm{g} / \mu \mathrm{L})$ and analyzed with the use of an epifluorescence microscope (Olympus, Leica). The chromosome number was analyzed in the control plants and individually for each regenerated R1 and R2 plant that had developed flower buds. Several to 88 metaphases were analyzed in each regenerated plant.

DNA probe and labelling

The rDNA probes used for fluorescent in situ hybridization were the following: (i) a $2.3-\mathrm{kb}$ ClaI fragment of the $25 \mathrm{~S}$ rRNA gene isolated from $A$. thaliana (Unfried and
Gruendler 1990), labelled with digoxigenin-11-dUTP (Roche) with the use of a nick translation kit (Roche) according to the manufacturer's protocol and immunodetected; and (ii) 5S rDNA (pTa794): a 410-bp clone isolated from Triticum aestivum (Gerlach and Dyer 1980) and labelled with rhodamine-5-dUTP (Roche) in a polymerase chain reaction.

Fluorescence in situ hybridization (FISH)

Slides used for chromosome number analysis were re-fixed in a mixture of $99.9 \%$ Et-OH : glacial acetic acid (3:1) for 2-3 min to remove the DAPI, rinsed with $99.9 \%$ ethanol, air dried and used for FISH experiments. Slides were incubated in $100 \mu \mathrm{g} / \mathrm{mL}$ RNase in $2 \times \mathrm{XSC}$ for $1 \mathrm{~h}$ at $37^{\circ} \mathrm{C}$ and rinsed three times in $2 \times \mathrm{SSC}$ at room temperature for $5 \mathrm{~min}$. They were then incubated in $10 \mathrm{mM} \mathrm{HCl}$ for $5 \mathrm{~min}$ at room temperature, treated with an $0.01 \mathrm{mg} / \mathrm{ml}$ pepsin solution for $15 \mathrm{~min}$ at $37^{\circ} \mathrm{C}$ and washed in $2 \times \mathrm{SSC}$. Subsequently, the slides were fixed in $1 \%$ formaldehyde in $1 \times$ PBS for $10 \mathrm{~min}$ and again rinsed three times in $2 \times$ SSC for $5 \mathrm{~min}$; then dehydrated in 70, 90 and $100 \%$ ethanol and air dried. The hybridization mixture containing $1 \mathrm{ng} / \mu \mathrm{L}$ of each DNA probe, $50 \%$ formamide, $10 \%$ dextran sulphate, $0.5 \%$ sodium dodecyl sulphate and $2 \mathrm{xSSC}$ was pre-denatured at $75^{\circ} \mathrm{C}$ for $10 \mathrm{~min}$ and stabilised on ice for $10 \mathrm{~min}$. A $38 \mu \mathrm{L}$ aliquot of the hybridization mixture was applied to the chromosome preparations, covered with a plastic coverslip and denatured together at $75^{\circ} \mathrm{C}$ for $5 \mathrm{~min}$ in an Omnislide Thermal Cycler. Hybridization was carried out at $37{ }^{\circ} \mathrm{C}$ in a humid chamber for $24 \mathrm{~h}$. Stringent washing of slides at $42{ }^{\circ} \mathrm{C}$ involved $2 \times \mathrm{SSC}$ for $5 \mathrm{~min}$, two changes of $20 \%$ formamide in $0.1 \times \mathrm{SSC}$ for $5 \mathrm{~min}$ and three changes of $2 \times \mathrm{SSC}$ for $3 \mathrm{~min}$. The Coplin jar was cooled to room temperature and slides were rinsed in $2 \times \mathrm{SSC}$ and $4 \times \mathrm{SSC} / \mathrm{Tween} 20$. In the case of the digoxygenin-labelled probe, $180 \mu \mathrm{L}$ of a $5 \%$ milk-blocking reagent was applied to each slide and incubated in a humid chamber at room temperature for $30 \mathrm{~min}$, then $45 \mu \mathrm{L}$ of fluorescein (FITC) conjugated anti-digoxigenin Fab fragments (Roche), at a concentration 1:11 in the $5 \%$ milk-blocking reagent was added. The slides were then incubated at $37{ }^{\circ} \mathrm{C}$ for $1 \mathrm{~h}$. After incubation, slides were washed in three changes of $4 \times \mathrm{SSC} /$ Tween 20 at $37{ }^{\circ} \mathrm{C}$, dehydrated and air dried. A Vectashield mounting medium containing $2.5 \mu \mathrm{g} / \mathrm{mL}$ DAPI was applied to the dry slides before adding coverslips. Slides were analyzed with the use of an epifluorescence microscope (OLYMPUS) with the appropriate filters. Pictures were taken with a CCD camera and processed with Adobe Photoshop software using only the functions that are applied equally to all pixels of the image. 


\section{Results and discussion}

\section{Regeneration}

In order to induce callus a young rosette leaves of the A. thaliana ecotype Columbia were used as explants. After 2 weeks of culture on callus-inducing medium some of the calli were transferred onto a shoot-inducing medium, and the rest was cultured on callus-inducing medium until the sixth week of culture, after which they were also transferred on to shoot-inducing media. The efficiency of the callus induction, estimated after 2 weeks, was $90 \%$. In both cases the first shoots were observed 8 weeks after the transfer of the calli and after 12 weeks of culture on shootinducing medium about $90 \%$ of them showed signs of regeneration. A higher number of shoots per callus was observed in the 2-week old calli (average 1.55 shoots per callus) than in the 6-week-old ones (1.0 shoot per callus). In both cultures about $80 \%$ of the regenerated rosettes developed roots after transferring them onto a root-inducing medium. The system of indirect organogenesis of $A$. thaliana, which is based on callus, shoot and root induction with the use of specific media allows for a high efficiency of regeneration; although it depends on the ecotype, the type of explant, the culture conditions and the medium and hormones employed (Negrutiu 1976; Akama et al. 1992; Candela et al. 2001). The composition of callus and shoot inducing media used here is recommended as efficient for induction of $A$. thaliana regeneration from leaf explants (Feldmann and Marks 1986, Fras and Maluszynska 2003). The time of preculture on callus inducing media is one of the crucial steps in the regeneration process. The short time of preculture has been shown to induce a generally higher capacity to produce shoots, but the feasibility of organogenesis is also dependent on the explant and ecotype used (Valvekens et al. 1988; Akama et al. 1992). The efficiency of the shoot production was slightly higher in the 2-weekold calli where more than one shoot per callus was observed.

\section{Cytogenetic analysis of starting materials}

The starting plant material was analyzed in order to exclude any cytogenetic variation that could influence further analysis. The levels of ploidy and endopolyploidy in rosette leaves from 3 week old plants were estimated. The flow cytometry measurements were conducted on 20 plants, and two samples from each plant were analyzed. All plants were found to be diploids. The young rosette leaves exhibited two cycles of endoreduplication and the maximum DNA content was 16C (Fig. 1a), which is consistent with the organ specific endopolyploidy pattern in $A$. thaliana (Galbraith et al. 1991). The chromosome number analysis was performed on root apical meristems of at least 20 seedlings as well as on flower buds collected individually from 20 plants. In the root apical meristems all metaphases had an exact diploid chromosome number $(2 \mathrm{n}=10)$, while in flower buds the diploid number occurred in $65 \%$ of the metaphases and the number of chromosomes in the remaining cells varied from 7 to 9 (Table 2). This phenomenon was defined as aneusomaty by Duncan (1945) and has been described for different types of organs and tissues in many species (D'Amato 1995). Although it was suggested that aneusomaty is more frequent in polyploids, for example in Artemisia czekanowskiana and A. macrantha (Pellicer et al. 2007), it was also noticed in species with a lower chromosome number, e.g. Deschampsia antarctica (Cardone et al. 2009). The rDNA sequences are robust chromosome markers for Arabidopsis thaliana and after applying FISH with these sequences as probes all chromosomes are easily distinguishable (Fransz et al. 1998). The distribution of $25 \mathrm{~S}$ and $5 \mathrm{~S}$ rDNA loci in the karyotype of control plants was analyzed in root tips and in flower buds. The first pair of chromosomes does not possess any rRNA genes, the second pair is characterized by the presence of $45 \mathrm{~S}$ rDNA site, the chromosomes of the third and the fifth pair bear 5S rRNA genes and the fourth pair has both $45 \mathrm{~S}$ and $5 \mathrm{~S}$ rDNA (Fig. 3a). These results confirm that the plants used as the starting material were uniform in the ploidy level, chromosome number and rDNA distribution.

\section{Ploidy of regenerants}

The ploidy of plants regenerated from both types of calli was determined by flow cytometry. Among the plants regenerated from the 2 -week-old calli three groups of plants at different ploidy levels were found-diploids (47\%), tetraploids (47\%) and octoploids (6\%) (Fig. 1b-d). The majority of the regenerants from the 6-week-old calli were diploids $(70 \%)$ and there were fewer tetraploids (30\%) and no octoploids (Table 1). The ploidy level was also analyzed in $56 \mathrm{R} 2$ plants produced from seeds obtained from diploid and tetraploid R1 plants. The flow cytometry showed that the progeny of diploid R1 plants were diploid and those of the tetraploid R1 plants were also tetraploid (Tab. 2).

Some of the regenerated plants showed differences in morphology. These phenotypic changes were particularly frequent among plants regenerated from the 2-week-old calli (Fig. 2). The type of morphology was often correlated with the ploidy level. Tetraploid and octoploid plants were shorter than diploids and had sturdy stems and leaves. Almost all of the plants, diploids as well as polyploids, regenerated from the 2 -week-old calli failed to produce seeds. The flowers were usually small, misshaped and 
Fig. 1 Flow cytometer histograms showing ploidy level and endopolyploidy patters of control plants (a) and regenerants from 2-week-old calli: (b) diploids;

(c) tetraploids; (d) octoploids
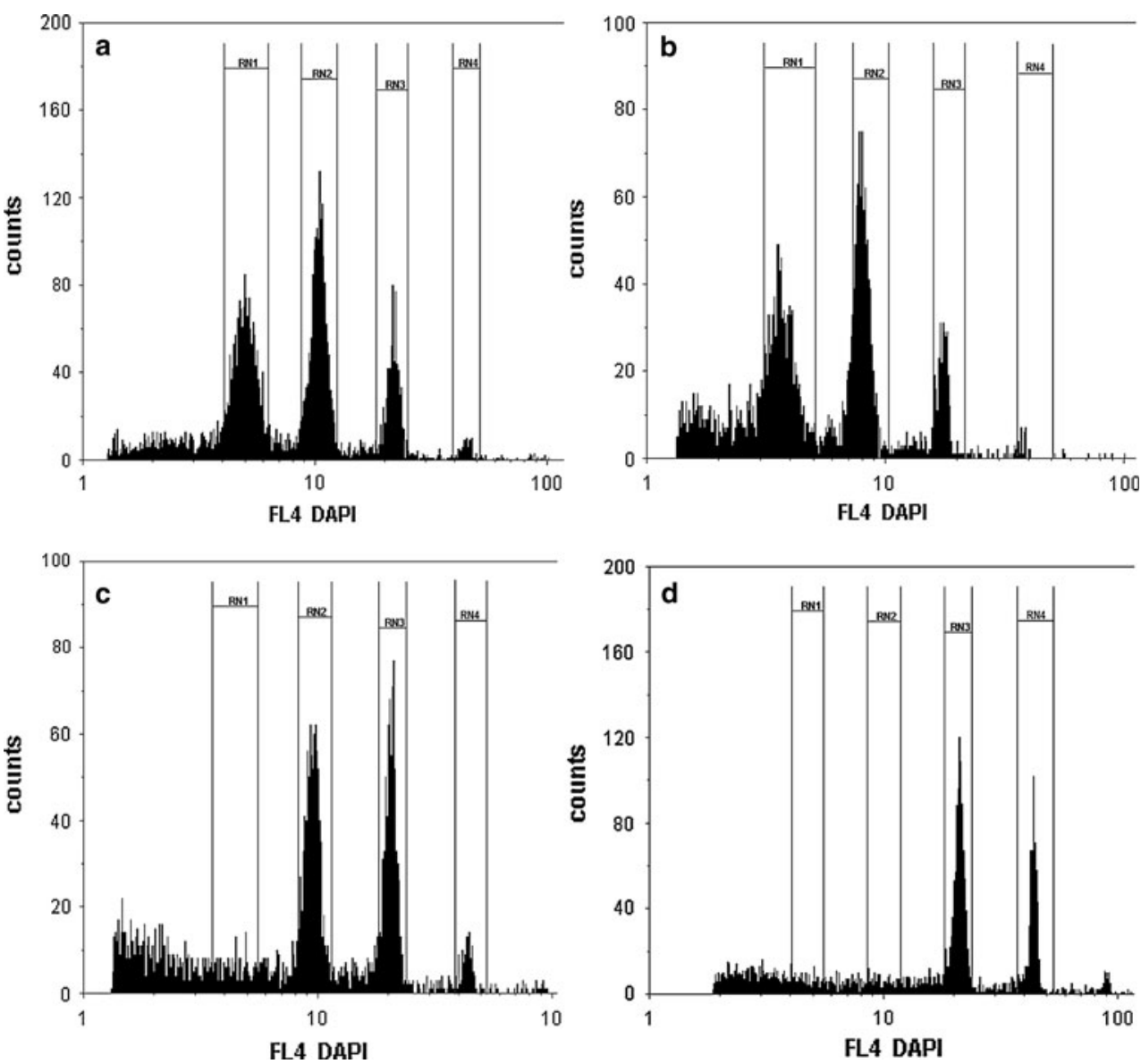

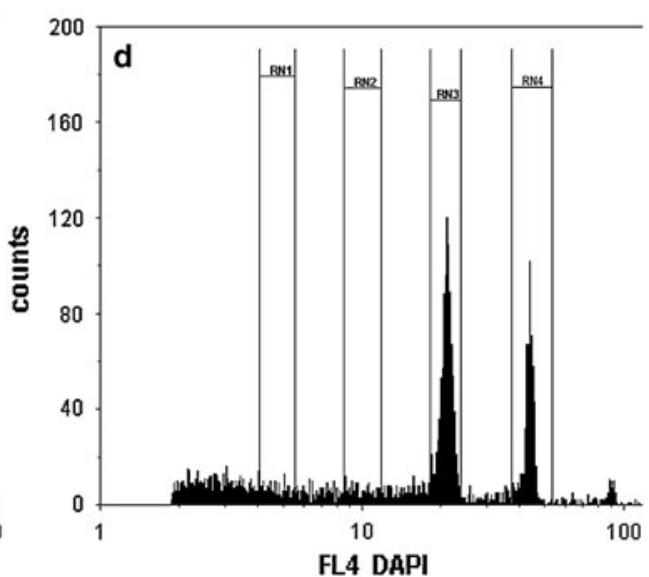

Table 1 Frequency of diploids and polyploids among regenerants from 2-week-old (R1-II) and 6-week-old calli (R1-VI)

\begin{tabular}{lll}
\hline $\begin{array}{l}\text { Ploidy of } \\
\text { regenerants }\end{array}$ & $\begin{array}{l}\text { R1 from 2-week-old } \\
\text { calli }(\%)\end{array}$ & $\begin{array}{l}\text { R1 from 6-week-old } \\
\text { calli }(\%)\end{array}$ \\
\hline Diploid & 47 & 70 \\
Tetraploid & 47 & 30 \\
Octoploid & 6 & - \\
\hline
\end{tabular}

withered away. Plants obtained from the 6-week-old calli showed similar malformations but only in $20 \%$ of the regenerants. Half of these regenerants had empty pods and $30 \%$ produced seeds, typically $1-23$ seeds per regenerant, which were used to produce the next generation (R2). Fifty-five percentage of the seeds produced normal growing R2 plants, while $45 \%$ did not germinate. Interestingly, in one case all of the seeds from one R1 regenerant failed to germinate, which may suggest the occurrence of serious disorders in the seed development.

The phenomenon of ploidy variation in plants regenerated in vitro has been observed in Arabidopsis as well as in other species (Clarindo et al. 2008; Jin et al. 2008; LemaRuminska 2011). There are several factors which can influence the ploidy level of the regenerants. Regeneration via organogenesis was said to induce greater variation than in case of somatic embryogenesis (Pontaroli and Camadro 2005). Gaj (2001) showed that all A. thaliana regenerants obtained through somatic embryogenesis were diploids. One of the most important factors which influence the ploidy level in regenerants is the type of explant. A ploidy level analysis of tomato somaclones from leaf, cotyledon and hypocotyl-derived callus confirmed that the mixoploidy of organs from polysomatic plants is the initial source of a ploidy variation in the in vitro culture (van den Bulk et al. 1990). The rosette leaves of A. thaliana used as explants in our experiments, were composed of cells with DNA contents from $2 \mathrm{C}$ to $16 \mathrm{C}$ (Fig. 1a). Moreover, Fras et al. (2007) showed that during the first days of callogenesis the cells of leaf explants from diploid Arabidopsis can reach 64C DNA level and cells with a tetraploid chromosome number are most frequent in callus after 4 days of culture. It was suggested that the stressful conditions of in vitro culture may cause endopolyploidization, abnormal microtubule arrangements and DNA damage, which may be responsible for polyploidization during the early stages of callogenesis. The frequency of polyploids among plants regenerated from 2-week-old calli may 
Fig. 2 Morphology of diploid (a), tetraploid (b) and octoploid (c) regenerants from 2-week-old calli
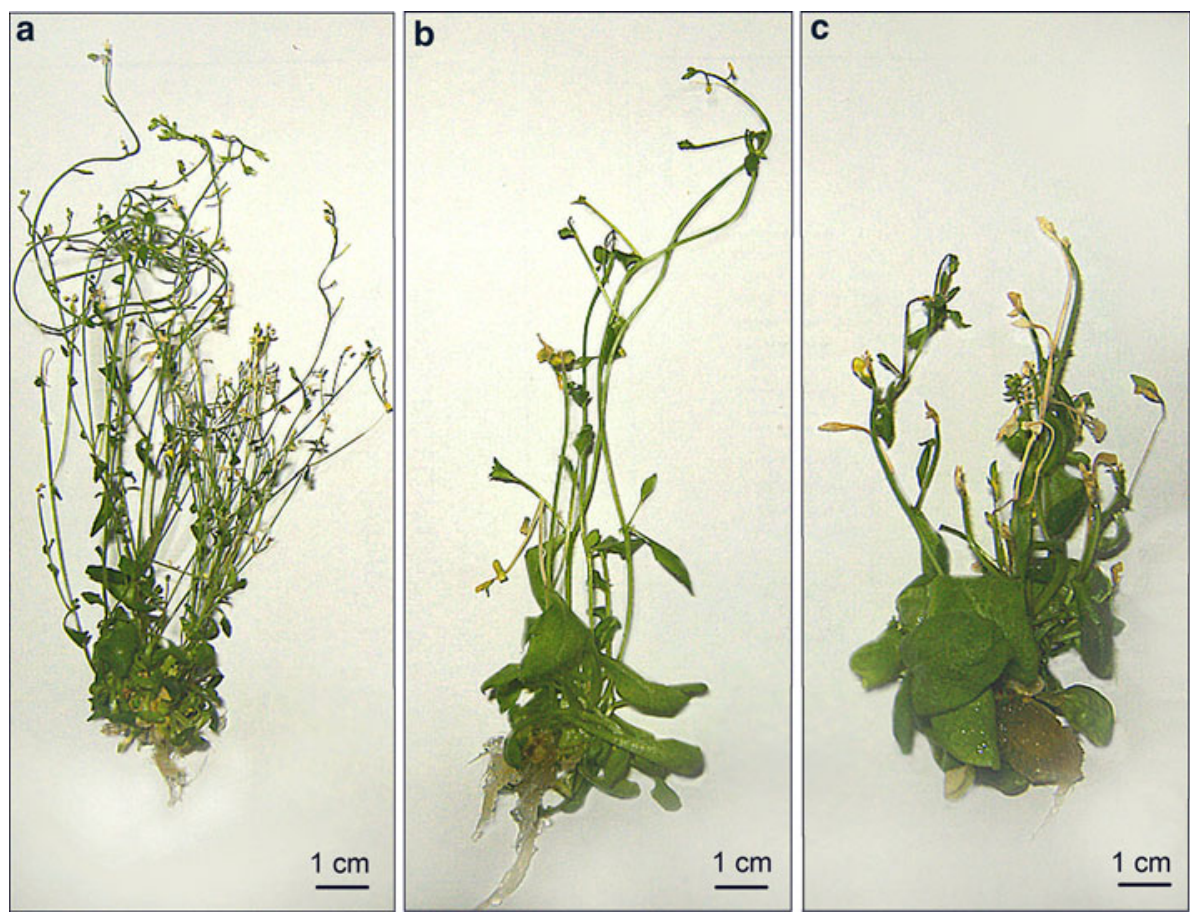

reflect a high level of polyploid cells in short aged calli. A lower frequency of polyploids was observed among regenerants from 6-week-old calli (Table 1). The analysis of regenerants derived from the five-month-old calli from leaf explants of the A. thaliana ecotype Wilna (Fras and Maluszynska 2003) showed a similar percentage of diploids as among plants from the 6-week-old calli used in our experiment. This is inconsistent with the common observations that as the period of culture goes on, the level of variation increases (Ziauddin and Kasha 1990; Jain 2001). It may suggest that in polysomatic plants the early preculture is a period of high polyploidization and in the following weeks of culture the ploidy variation is established at a lower level, at least for some time.

\section{Chromosome number analysis}

The flow cytometry is an excellent tool to estimate the ploidy level in a large number of specimens. Only a small part of a plant, e.g. leaf, is used for DNA measurements, while other parts can be used for a further analysis. However, while the flow cytometry technique allows for the identification of the ploidy level of the regenerated plants, the presence of aneuploid cells in the analyzed material could not be recognized (Sree Ramulu and Dijkhuis 1986). Therefore additional analyses of chromosome number analysis should be undertaken. In the present study we exploited the floral buds for the analysis of chromosome number. The ploidy level was established for all regenerated plants. Among these chromosome counting was performed for $35 \mathrm{R} 1$ plants which had developed flower buds and for $18 \mathrm{R} 2$ plants. As the analysis of the chromosome number in flower buds of the control plants showed aneusomaty, the variation in the chromosome number in the regenerants was compared with the variation in the control plants. R1 plants from the 2-week-old calli showed the highest variation in the chromosome number. In most diploid regenerants there were about $50 \%$ metaphases with 10 chromosomes and the remaining cells were mainly hypodiploid. Among the tetraploid regenerants only about $30 \%$ of the cells had 20 chromosomes, while $50 \%$ of the cells had 16-19 chromosomes. A wide variation in the chromosome number, ranging from 11 to 76, was observed in the octoploid regenerants, although almost half of the cells had 36-39 chromosomes. The chromosome number in R1 plants from the 6-week-old calli did not vary significantly. On average $89 \%$ of the analyzed metaphases had 10 chromosomes in diploids and in case of tetraploids $79 \%$ of metaphases had 20 chromosomes. The chromosome number in R2 was counted in flower buds, as was the case for R1 plants. In the diploid R2 plants the percentage of cells with $2 \mathrm{n}=10$ was even higher than in the control plants and equalled $90 \%$. In the tetraploids $72 \%$ of the cells had $2 \mathrm{n}=4 \mathrm{x}=20$ chromosomes (Table 2).

The regenerants at each ploidy level exhibited a tendency to lose chromosomes which led to aneuploid cells. The number of cells with missing chromosomes was positively correlated with the ploidy level of the regenerants. The dominance of the hypotetraploid cells in plants regenerated in vitro was observed in potato $(2 \mathrm{n}=4 \mathrm{x}=48)$ and can be 
Table 2 Frequency of cells with a different chromosome number in roots and flower buds of control plants (K-roots, K-flowers) and plants regenerated from 2- and 6-week-old calli

\begin{tabular}{|c|c|c|c|c|c|c|c|c|c|c|}
\hline \multirow[t]{2}{*}{ Group of plants } & \multirow{2}{*}{$\begin{array}{l}\text { Ploidy by flow } \\
\text { cytometry }\end{array}$} & \multirow{2}{*}{$\begin{array}{l}\text { Number of } \\
\text { plants (cells) } \\
\text { analysed }\end{array}$} & \multicolumn{8}{|c|}{ Mean frequency of metaphases with a different chromosome number (\%) } \\
\hline & & & Нyро- $2 \mathrm{x}$ & $2 \mathrm{x}$ & Hyper-2x & $4 \mathrm{x}$ & Hyper-4x & Нypo-8x & $8 \mathrm{x}$ & $8 \mathrm{x}<$ \\
\hline Control-roots & Diploids & $20(100)$ & - & 100 & - & - & - & - & - & - \\
\hline Control-flowers & Diploids & $20(200)$ & 35 & 65 & - & - & - & - & - & - \\
\hline \multirow{3}{*}{$\begin{array}{l}\text { R1 from 2-week } \\
\text { callus }\end{array}$} & Diploids & 7 (384) & 33.6 & 50.5 & 12.2 & 3.1 & 0.5 & - & - & - \\
\hline & Tetraploids & $4(178)$ & 1.6 & 9.5 & 50.0 & 29.8 & 8.9 & - & - & - \\
\hline & Octoploids & $2(60)$ & - & - & 7.8 & 1.7 & 16.3 & 49.4 & 9.6 & 25.2 \\
\hline \multirow{2}{*}{$\begin{array}{l}\text { R1 from 6-week } \\
\text { callus }\end{array}$} & Diploids & $16(640)$ & 4.0 & 89.1 & 4.1 & 4.5 & - & - & - & - \\
\hline & Tetraploids & $6(292)$ & - & 13.0 & 6.2 & 79.4 & 1.4 & - & - & - \\
\hline \multirow[t]{2}{*}{$\mathrm{R} 2$} & Diploids & $2(100)$ & 7 & 90.0 & 3 & - & - & - & - & - \\
\hline & Tetraploids & $16(713)$ & - & - & 23.5 & 72.0 & 4.5 & - & - & - \\
\hline
\end{tabular}

explained by a better tolerance of the aneuploid state in cells with more than one genome (Jelenić et al. 2001). An analysis of the chromosome number in A. thaliana regenerants shows that plants regenerated from the 2-week-old calli, displayed not only a wider ploidy variation but also a higher instability of the chromosome number. This could explain the altered morphology and infertility of the regenerants.

Apart from the aneusomaty of the flower buds tissue the mixoploidy of somaclones can be a reason for chromosome number variation. It was observed by several authors, for example in Solanum tuberosum (Jelenić et al. 2001; Sree Ramulu et al. 1983), Asparagus officinalis (Kunitake et al. 1998; Pontaroli and Comadro 2005) and Carica papaya (Clarindo et al. 2008). One of the explanations for this phenomenon is the cytological diversity of the cells involved in the organisation of an adventitious bud (Christianson and Warnick 1983). Brutovská et al. (1998) noticed the influence of growth regulators such as high concentrations of BA in a medium on the frequency of mixoploidy among the Hypericum perforatum regenerants.

\section{Karyotype analysis with FISH}

The next step in our investigations was an examination of the chromosomal distribution of 5S and 45S rDNA loci, which aimed at analyzing the structure of the chromosomes and identify missing or additional chromosomes in aneuploid cells. Plants from the 2-week-old calli had small and deformed flower buds with a low number of dividing cells. For this reason only a small number of cells could be analyzed by FISH for one representative of each ploidy level. In the analyzed plants the rearrangements of rDNA loci was accompanied by a high variation in the chromosome number which hindered the identification of particular chromosomes. It was difficult to determine what types of structural aberrations occurred and which chromosomes were involved in the rearrangements. In plants from the 6-weekold calli the variation in chromosome number was not so high making it possible to analyse the aberrations. The number and localization of $45 \mathrm{~S}$ and $5 \mathrm{~S}$ rDNA sequences was studied in 14 diploid and 6 tetraploid regenerants from a total of 496 metaphases. Metaphases with a correct chromosome number and position of rDNA loci were predominant in both diploid and tetraploid regenerants, 59 and $73 \%$, respectively. In the remaining cells rearrangements of rDNA loci and/or aneuploid chromosome numbers were observed (Fig. 3b-d). Moreover, various types of structural aberrations occurred in the cells from individual plants. For example, one of the diploid regenerants showed different types of structural rearrangements such as rDNA translocation, deletion and duplication. In the tetraploid regenerants, several types of aberrations could also be recognized in one metaphase (Fig. 4a). In all of the analyzed karyotypes no correlation between the type of mutation and a particular pair of chromosomes was found, which indicates that the chromosomes are subjected randomly to the structural rearrangements. The exception were the tetraploid regenerants where deletions of $5 \mathrm{~S}$ rDNA loci were slightly more common than deletions of $45 \mathrm{~S}$ rDNA. A comparison of frequency of a particular aberration type in diploids and tetraploids showed interesting results. Among diploid plants the most frequent type of rearrangements were translocations, while in tetraploids deletions, especially of $5 \mathrm{~S}$ rDNA. Duplications of the rDNA sequences had the lowest frequency and their number was equal in diploids and tetraploids (Fig. 5). One explanation for the higher level of deletions observed in tetraploid regenerants may be a better tolerance to the loss of the DNA sequence in the presence of additional copies in polyploid cells rather than in diploid ones. 


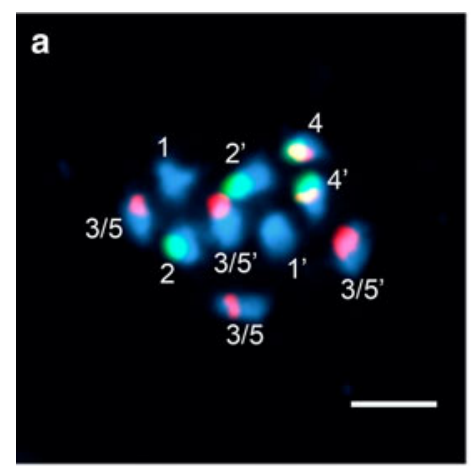

CONTROL $2 x=10$
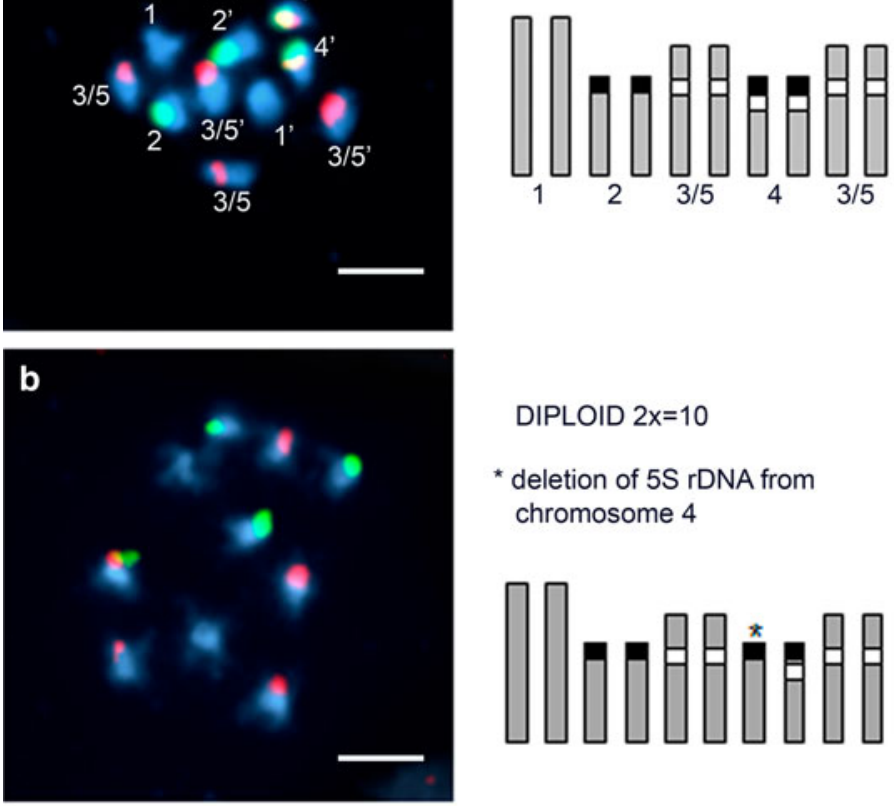

DIPLOID $2 x=10$

* deletion of 5S rDNA from chromosome 4
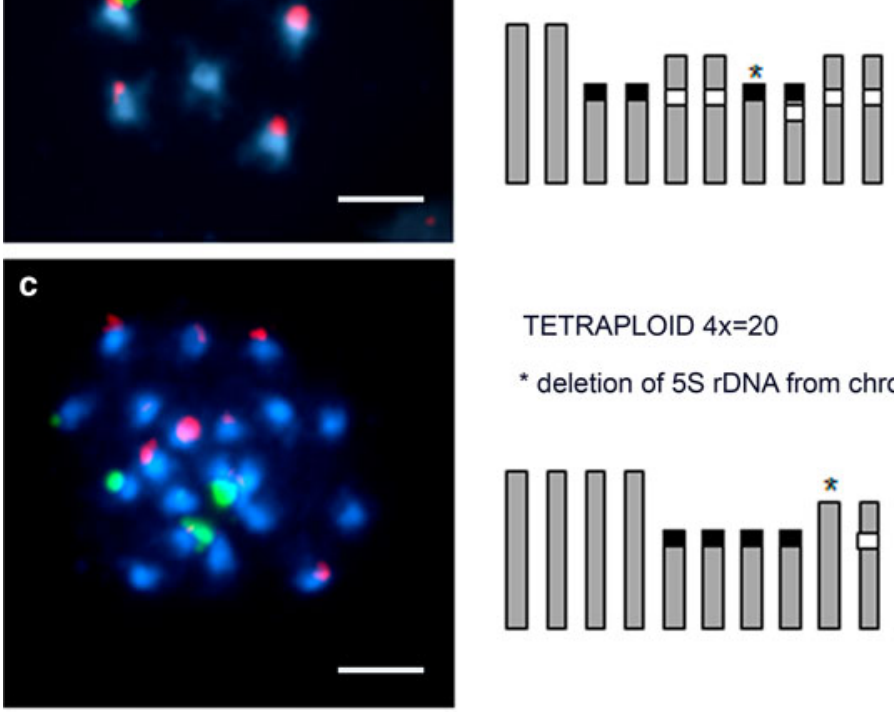

TETRAPLOID $4 \mathrm{x}=20$

* deletion of $5 \mathrm{~S}$ rDNA from chromosome $3 / 5$
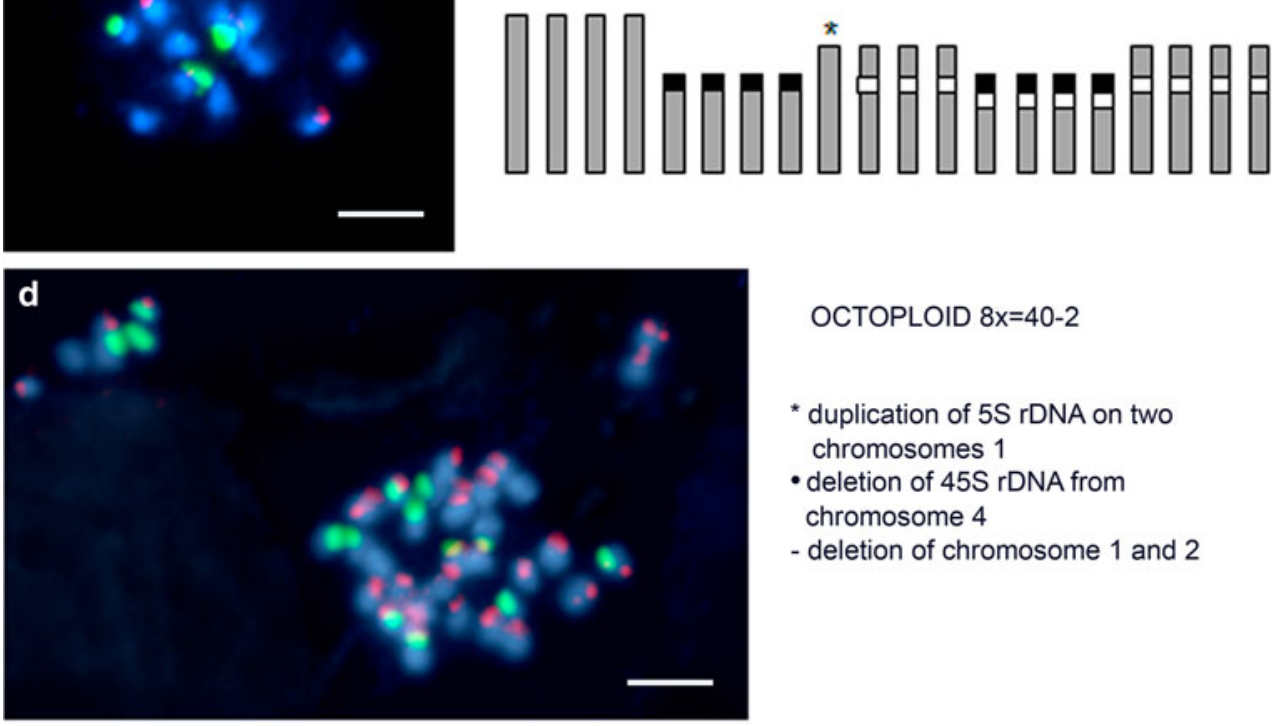

OCTOPLOID $8 x=40-2$

* duplication of 5S rDNA on two

chromosomes 1

- deletion of 45S rDNA from

chromosome 4

- deletion of chromosome 1 and 2

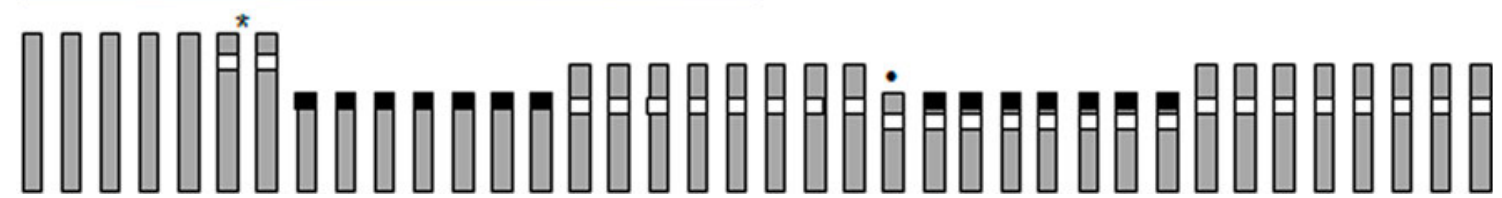

Fig. 3 FISH with 45S rDNA and 5S rDNA on chromosomes of $A$. thaliana plants. (a) Control plant 2x $=10$; (b-d)-regenerants from 2-weekold calli; (b) diploid regenerant; (c) tetraploid regenerant; (d) octoploid regenerant. Bar $10 \mu \mathrm{m}$ 
Fig. 4 FISH with $45 \mathrm{~S}$ rDNA and $5 \mathrm{~S}$ rDNA on chromosomes of A. thaliana regenerants. (a) tetraploid regenerant from 6-week-old calli; (b) tetraploid plant from R2 generation of regenerants. Bar $10 \mu \mathrm{m}$

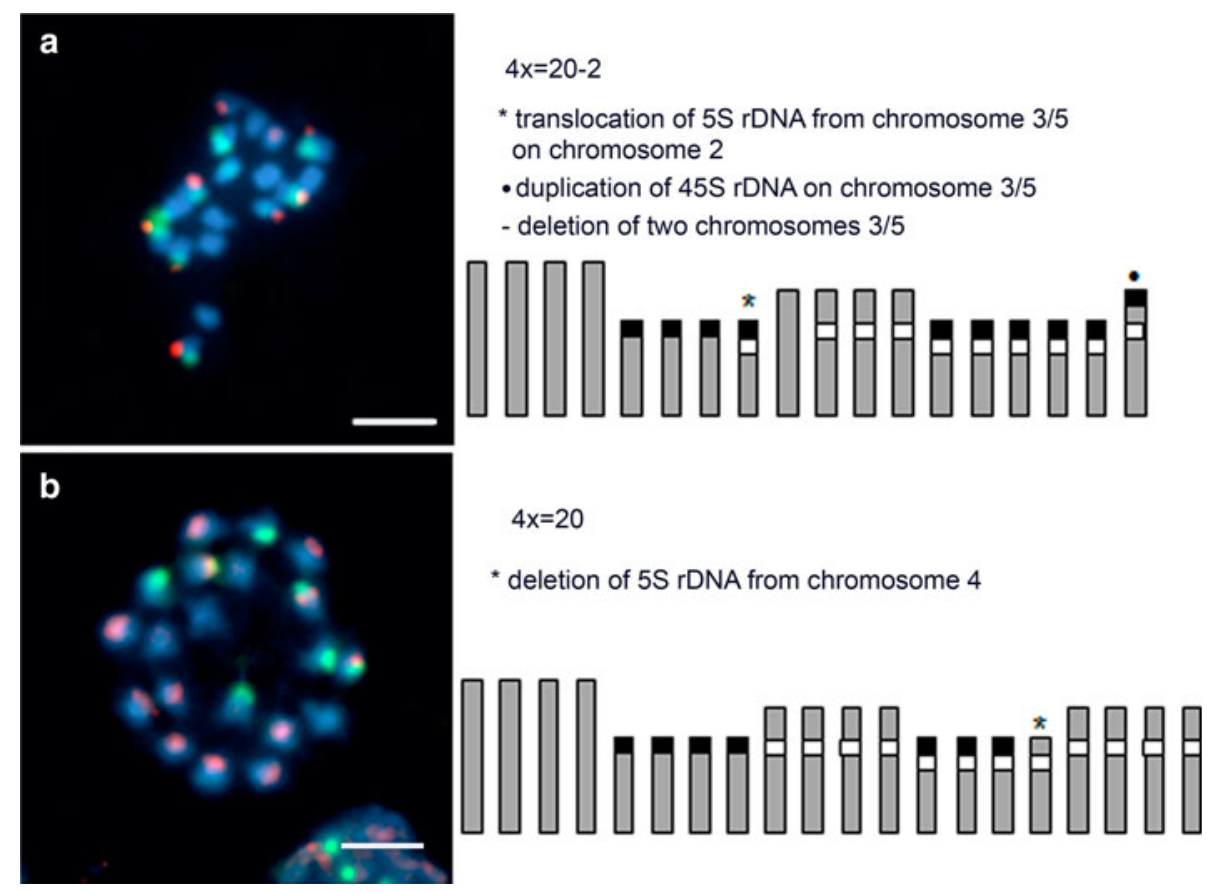

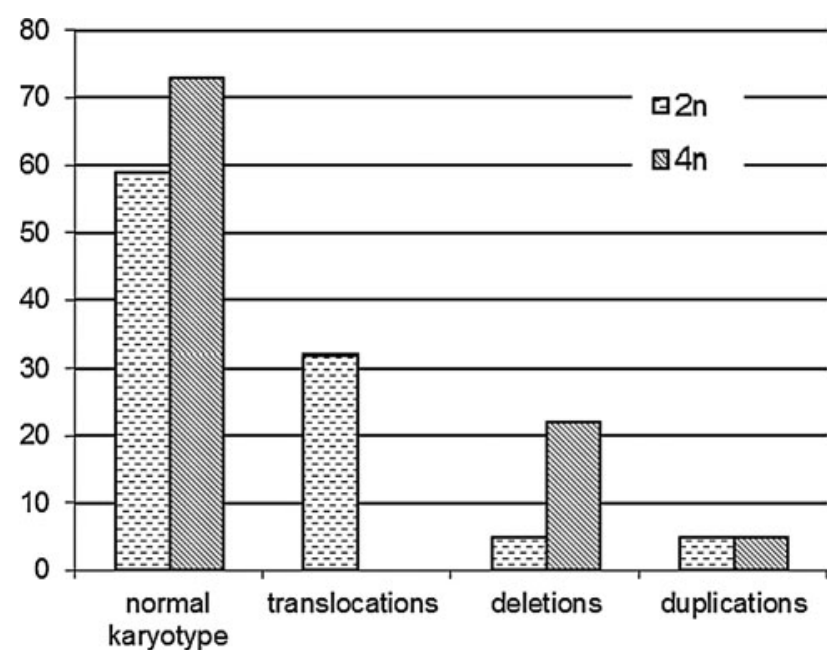

Fig. 5 Frequency of different types of structural aberrations among diploid and tetraploid plants from 6-week-old calli

The localization of rDNA loci was studied in 5 plants from the R2 generation, two diploids and three tetraploids, which were the progeny of two R1 regenerants. The diploids exhibited a normal karyotype, while in all the tetraploid plants deletion of $45 \mathrm{~S}$ rDNA from one chromosome 4 was observed (Fig. 4b).

An analysis of FISH signals in the aneuploid cells of regenerants from the 6-week-old calli enabled identification of additional and missing chromosomes in these cells (Figs. 3d, 4a), but among the 34 cells analyzed no preference was noticed. FISH with rDNA probes has proved to be useful in karyotype examination in plants regenerated in vitro. In the tetraploid species A. tuberosum $(2 \mathrm{n}=4 \mathrm{x}=32)$ about $40 \%$ of somaclones were hypotetraploid, and FISH with rDNA probes confirmed the identification of missing chromosomes in variants with 29, 30 and 31 chromosomes. In each of these variants, different chromosomes of the karyotype were lost (Do et al. 1999, 2000).

Many cytological studies have reported alterations in chromosome number in plants regenerated in vitro, although there are fewer reports on structural rearrangements, generally because such analyses are time-consuming and often tedious. Kharabian and Darabi (2005) analyzed aberrations in regenerants of two Oryza sativa cultivars in prometaphase mitotic and meiotic chromosomes stained with Giemsa. Changes in chromosomal structure like deficiencies, duplications and translocations were detected. It is relevant that these aberrations involved various chromosomes among particular regenerated plants. These data, together with our present results, suggest that the structural rearrangements are random as it was observed for numerical aberrations. The level and type of cytogenetic changes depends on a number of factors. In our research the influence of the preculture period was evaluated, but also using of different type of explant or ecotype can result in a different response. For instance, structural chromosome abnormalities have not been detected during molecular analysis of A. thaliana regenerants obtained from root explants after 1 week of preculture on callus inducing medium (Jiang et al. 2011). 


\section{Conclusions}

Ploidy and chromosome number analysis of plants regenerated from calli after different periods of preculture suggests that the 2-week-old calli displays a higher frequency of polyploid cells which influence the ploidy of regenerants. Diploids, tetraploids and octoploids were observed among plants produced from these calli, and a high variation in the chromosome number in these regenerants was found. Variation in chromosome number, particularly a high frequency of aneuploid cells, probably influence the morphology and fertility of regenerants derived through organogenesis from short-aged calli. Only diploid and tetraploid plants were regenerated from the 6-week-old calli. In these plants a low frequency of aneuploid cells was detected and they were able to produce seeds.

FISH with rDNA probes revealed structural as well as numerical aberrations in the cells of the regenerated plants. Significantly, no preference of any type of aberrations to a particular chromosome or chromosome segment was distinguished. The correlation between the structural aberration type and the ploidy of regenerants is noticeable. In diploid regenerants translocations of rDNA loci were the most frequent type of mutation, while deletions occurred most often in tetraploids. The progeny of $\mathrm{R} 1$ regenerants exhibited the same chromosome number as their parents, and structural rearrangements were transmitted.

Open Access This article is distributed under the terms of the Creative Commons Attribution License which permits any use, distribution, and reproduction in any medium, provided the original author(s) and the source are credited.

\section{References}

Akama K, Shiraishi H, Ohta S, Nakamura K, Okada K, Shimura Y (1992) Efficient transformation of Arabidopsis thaliana: comparison of the efficiences with various organs, plant ecotypes and Agrobacterium strains. Plant Cell Rep 12:7-11

Bairu MW, Aremu AO, Van Staden J (2011) Somaclonal variation in plants: causes and detection methods. Plant Growth Regul 63(2): 147-173

Brutovská R, Čellárová E, Doležel J (1998) Cytogenetic variability of in vitro regenerated Hypericum perforatum L. plants and their seed progenies. Plant Sci 133:221-229

Candela M, Velázquez L, De La Cruz B, Sendino AM, De La Peňa A (2001) Differences in in vitro plant regeneration ability among four Arabidopsis thaliana ecotypes. In Vitro Cell Dev Biol-Plant 37:638-643

Cardone S, Sawatani P, Rush P, Garcia AM, Poggio L, Schrauf G (2009) Karyological studies in Deschampsia Antarctica Desv. (Poaceae). Polar Biol 32:427-433

Christianson ML, Warnick DA (1983) Competence and determination in the process of in vitro shoot organogenesis. Dev Biol 95:288-293

Clarindo WR, de Carvalho CR, Araújo FS, de Abreu IS, Otoni WC (2008) Recovering polyploid papaya in vitro regenerants as screened by flow cytometry. Plant Cell Tiss Organ Cult 92:207-214
D'Amato F (1989) Polyploidy in cell differentiation. Caryologia 42(3-4):183-211

D'Amato F (1995) Aneusomaty in vivo and in vitro in higher plants. Caryologia 48(2):85-103

Do G-S, Seo B-B, Ko J-M, Lee S-H, Pak J-H, Kim I-S, Song S-D (1999) Analysis of somaclonal variation through tissue culture and chromosomal localization of rDNA sites by fluorescent in situ hybridization in wild Allium tuberosum and a regenerated variant. Plant Cell Tiss Organ Cult 57:113-119

Do G-S, Seo B-B, Pak J-H, Kim I-S, Song S-D (2000) Karyotypes of three somaclonal variants and wild Plants of Allium tuberosum by bicolor FISH. J Plant Biol 43(3):143-148

Dolezel J, Greilhuber J, Lucretti S, Meister A, Lysak MA, Nardi L (1998) Plant genome size estimation by flow cytometry: interlaboratory comparison. Ann Bot 82:17-26

Duncan RE (1945) Production of variable aneuploid numbers of chromosomes within the root tips of Paphiopedilum wardii. Amer J Bot 32:506-509

Feldmann KA, Marks MD (1986) Rapid and efficient regeneration of plants from explants of Arabidopsis thaliana. Plant Sci 47:63-69

Fransz P, Armstrong S, Alonso-Blanco C, Fischer TC, Torres-Ruiz RA, Jones G (1998) Cytogenetics for the model system Arabidopsis thaliana. Plant J 13(6):867-876

Fras A, Maluszynska J (2003) Regeneration of diploid and tetraploid of plants of Arabidopsis thaliana via callus. Acta Biol Crac Ser Bot 45(2):145-152

Fras A, Juchimiuk J, Siwinska D, Maluszynska J (2007) Cytological events in explants of Arabidopsis thaliana during early callogenesis. Plant Cell Rep 26:1933-1939

Gaj MD (2001) Direct somatic embryogenesis as a rapid efficient system for in vitro regeneration of Arabidopsis thaliana. Plant Cell Tiss Organ Cult 64:39-46

Galbraith DW, Harkins KR, Knapp S (1991) Systemic endopolyploidy in Arabidopsis thaliana. Plant Physiol 96:985-989

Gamborg OL, Miler RA, Ojima K (1968) Nutrient requirement of suspension cultures of soybean root cells. Exp Cell Res 50:151-158

Gerlach WL, Dyer TA (1980) Sequence organization of the repeating units in the nucleus of wheat which contain 5S rRNA genes. Nucleic Acids Res 11:4851-4865

Hasterok R, Wolny E, Hosiawa M, Kowalczyk M, Kulak-Ksiazczyk S, Ksiazczyk T, Heneen WK, Maluszynska J (2006) Comparative analysis of rDNA distribution in chromosomes of various species of Brassicaceae. Ann Bot 97:205-216

Jain MS (2001) Tissue-culture derived variation in crop improvement. Euphytica 118:153-166

Jelenić S, Berljak J, Papeš D, Jelaska S (2001) Mixoploidy and chimeric structures in somaclones of potato (Solanum tuberosum L.) cv Bintje. Food Technol. Biotechnol 39(1):13-17

Jiang C, Mithani A, Gan X, Belfield EJ, Klingler JP, Zhu J-K, Ragoussis J, Mott R, Harberd NP (2011) Regenerant Arabidopsis lineages display a distinct genome-wide spectrum of mutations conferring variant phenotypes. Curr Biol 21:1385-1390

Jin S, Mushke R, Zhu H, Tu L, Zhang Y, Zhang X (2008) Detection of somaclonal variation of cotton (Gosypium hirsutum) using cytogenetics, flow cytometry and molecular markers. Plat Cell Rep 27:1303-1316

Karp A (1995) Somaclonal variation as a tool for crop improvement. Euphytica 85:295-302

Kharabian A, Darabi A (2005) Characterization of some chromosomal aberrations in regenerated rice plants. Plant Cell Tiss Organ Cult 83:161-168

Kunitake H, Nakashima T, Mori K, Tanaka M (1998) Somaclonal and chromosomal effect of genotype, ploidy and culture duration in Asparagus officinalis L. Euphytica 102:309-316

Lee M, Phillips RL (1988) The chromosomal basic of somaclonal variation. Ann. Rev. Plant Physiol. Plant Mol Biol 39:413-437 
Lema-Ruminska J (2011) Flow cytometric analysis of somatic embryos, shoots, and calli of the cactus Copiapoa tenuissima Ritt. Forma monstruosa. Plant Cell Tiss Organ Cult 106:531-535

Lysak MA, Fransz PF, Ali HBM, Schubert I (2001) Chromosome painting in Arabidopsis thaliana. Plant J 28(6):689-697

Mallón R, Rodríguez-Oubiňa J, González ML (2010) In vitro propagation of the endangered plant Centaurea ultreiae: assessment of genetic stability by cytological studies, flow cytometry and RAPD analysis. Plant Cell Tiss Organ Cult 101:31-39

Molnar-Lang M, Linc G, Friebe BR, Sutka J (2000) Detection of wheat-barley translocations by genomic in situ hybridization in derivatives of hybrids multiplied in vitro. Euphytica 112: $117-123$

Murashige T, Skoog F (1962) A revised medium for rapid growth and bioassays with tobacco tissue cultures. Physiol Plantarum 15:473-497

Negrutiu I (1976) In vitro morphogenesis in Arabidopsis thaliana. Arabidopsis Inf Serv 12:27-29

Pellicer J, Garcia S, Garnatje T, Dariimaa S, Korobkov AA, Vallès J (2007) Chromosome numbers in Artemisia (Asteraceae, Anthemidaeae) species and genome size variation in its subgenus Dracunculus: karyological, systematic and phylogenetic implication. Chromosome Botany 2:45-53

Peschke VM, Phillips RL (1992) Genetic implications of somaclonal variation in plants. Adv Gen 30:41-66

Phillips RL, Kaeppler SM, Olhoft P (1994) Genetic instability of plant tissue cultures: breakdown of normal controls. Proc Nat Acad Sci USA 91:5222-5226
Pontaroli AC, Camadro EL (2005) Somaclonal variation in Asparagus officinalis plants regenerated by organogenesis from long term callus cultures. Gen Mol Biol 28(3):423-430

Prado MJ, Rodriguez E, Rey L, González MV, Santos C, Rey M (2010) Detection of somaclonal variants in somatic embryogenesis-regenerated plants of Vitis vinifera by flow cytometry and microsatellite markers. Plant Cell Tiss Cult 103:49-59

Sree Ramulu K, Dijkhuis P, Roest S (1983) Phenotypic variation and ploidy level of plants regenerated from protoplasts of tetraploid potato (Solanum tuberosum L. cv. 'Bintje'). Theor Appl Genet 65:329-338

Unfried I, Gruendler P (1990) Nucleotide sequence of the 5.8S and $25 \mathrm{~S}$ rRNA genes and the internal transcribed spacers from Arabidopsis thaliana. Nucleic Acids Res 18:4011

Valvekens D, Van Montagu M, Van Lijsebettens M (1988) Agrobacterium tumefaciens-mediated transformation of Arabidopsis thaliana root explants by using kanamycin selection. Proc Natl Acad Sci USA 85:5536-5540

van den Bulk RW, Löffler HJM, Lindhout WH, Koornneef M (1990) Somaclonal variation in tomato: effect of explant source and a comparison with chemical mutagenesis. Theor Appl Genet 80:817-825

Zhao J, Cui J, Liu J, Liao F, Henny R, Chen J (2012) Direct somatic embryogenesis from leaf and petiole explants of Spathiphyllum 'Supreme' and analysis of regenerants using flow cytometry. Plant Cell Tiss Organ Cult. doi:10.1007/s11240-012-0146-5

Ziauddin A, Kasha KJ (1990) Long-term callus cultures of diploid barley (Hordeum vulgare). II. Effect of auxins on chromosomal status of cultures and regeneration of plants. Euphytica 48:279-286 